\title{
ICТОРІЯ УКРАЇНИ
}

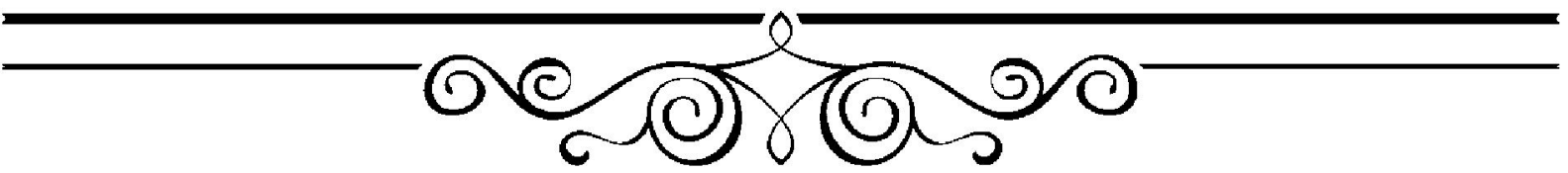

УДК 94: 338.45(477)"1920"

DOI: 10.31651/2076-5908-2021-2-45-51

\author{
PERGA Tetiana, \\ $\mathrm{PhD}$ in History, senior researcher, \\ State Institution "Institute of World History \\ of National Academy of Science of Ukraine" \\ Orchid ID: 0000-0002-8725-3451 \\ e-mail: pergatatiana@gmail.com
}

\section{JEWISH WOMAN ARTISANS IN THE UKRAINIAN SSR IN 1920s: FIGHT OR ADAPT?}

Introduction. The article examines the scientific problem of the participation of Jewish women in the industrial labor, in particular in handicrafts. The situation in the Ukrainian SSR in 1920s was taken as the basis for the research. Novelty. Relevance of the research is determined by the non-disclosure of this topic in the scientific works of the Ukrainian and foreign experts. Purpose of the article is to disclosure the peculiarities of the participation of Jewish women in the handicraft industry in the 1920s.

Methods. The source base of the study is the statistical data of the censuses took place in the Russian Empire and in the USSR, specialized surveys of economic activity of Jews before and after 1917, as well as archival materials. Author conducted a comparative analysis of the involvement of Jewish women in artisanship in the Russian Empire and the USSR (Ukrainian SSR).

Results. It has been concluded that the main reasons for the employed of Jewish women in handicrafts in both empires were economic. The peculiarities of work of Jewish women in handicraft production, their age and professional structure are revealed. Author made a conclusion that during the multivector economic policy of the Soviet government (war communism, NEP, industrialization) in the 1920s, Jewish women artisans were forced to wage a daily struggle for survival and confront many problems. They are following: arbitrariness of authorities, especially during taxation; lack of raw materials and access to public loans; high competition in the environment of artisans and with the factory industry; combination of work with raising of children; low level of education and mechanization of labor, etc. ORT provided significant assistance to artisans, but it could not meet all the needs of artisans in equipment.

Conclusions. The Soviet government's policy on the cooperation of artisans posed a dilemma for women artisans: to unite in joint enterprises (artels) or to join the ranks of workers in various enterprises, mostly industrial. Crafts especially related to fabric processing, were abandoned mainly as additional underground earnings.

Key words: Jews, women, artisans, handicrafts, economy, NEP, USSR, Ukrainian SSR, Russian Empire.

Introduction. The gender aspect of the industrial labor of Jews in the early Soviet Union has not been explored sufficiently. Neither the Russian Empire nor the Soviet Union has carried out special in-depth studies on this subject; there are only a few scattered figures. Meanwhile, the study of this aspect will help us to reveal some aspects of the economic history of Jews, in particular, the features of the employment of Jewish women and their integration into the Soviet economy in the $1920 \mathrm{~s}-1930$ s.

Originality. The participation of Jewish women in industrial labor is currently insufficiently studied. In fact, the only study that attempted to investigate this aspect is a monograph of $\mathrm{O}$. Kozerod «Gender aspect of the history of Ukrainian Jewry» [1]. At the same time, it focuses 
more on the participation of Jewish women in the political, cultural and social life, while the economic aspects need to be further developed. Some fragmented data on the development of handicrafts in the USSR can be found in the numerous works of the Ukrainian and foreign researchers of the NEP period. For example, O.Yevsyukova demonstrated a portrait of Jewish artisans in Kharkiv region. Scientific articles by O. Krichker, A. Morozov, V. Gusev, N.M Chashko and others analyzed activities of handicrafts and artisans in shtetls located in Ukraine as well as participation of Jews in the cooperative movement. At the same time, these studies do not focus on the activities of Jewish artisans of Kyiv region. As for the assistance of ORT to the Jewish population of the Soviet Union, it is mentioned in many scientific works, but deep analysis of the activities of Kyiv ORT Committee has not yet been analyzed. This requires us to fill the existing scientific lacuna.

Purpose. In this article, we intend to summarize scattered data and disclosure the peculiarities of the participation of Jewish women in the handicraft industry in the 1920s. To accomplish this task, we will conduct a comparative analysis of the participation of Jewish women in the handicraft industry in the Russian Empire and in the USSR.

Methodology. For analysis of the main trends we will use data of census and statistical research conducted in the Russian Empire $(1897,1908,1915)$ and in the Sovier Union (1926, 1939), as well as of archival materials and the Soviet newspapers.

Results. It is hard to arrive at a satisfactory definition of the concept «artisan», although it is very widely used. For the purposes of this paper artisant is a person who does skilled work with his or her hands [2]. Many peasants were engaged in various crafts supplemented to agricultural labor in the Russian Empire. We consider craft as a job or activity that needs skill and experience, an occupation with the aim of obtaining a benefit that can provide, in whole or in part, the income necessary for life [4].

According to the 1897 General Census of the Russian Empire, 2,4 million of Jews (10,1\% of total population) lived in 15 provinces within the Jewish Pale of Settlement [4]. The employment rate of Jews (age group 15-24 year-olds) was $45,1 \%$, of which $74 \%$ were men and $18 \%$ were women. Given historical circumstances of living Jews on the Russian empire majority of them were engaged in trade $(38,65 \%)$ and crafts $(35,43 \%)$ [5, 12-13]. Until 1917, there were 16 times more artisans among Jews than from other ethnic groups combined. From 1872 to 1897, the number of Jewish artisans increased 6 times and reached 120,971 people in the Kyiv, Podolsk and Volyn provinces. There were 19,1 tailors, 14,4 shoemakers, 6,0 carpenters, 4,6 bakers, 4,4 butchers per 100 Jewish artisans [6].

Female and child labor was highly developed in the Russian Empire. In 1897, a total number of 76548 Jewish women worked in various trades and crafts according to the questionnaire of the Jewish colonization society [7, 130-132]. Most of them were family members of man-artisans so they were engaged in the family business. However, official statistics does not show their number. Women mainly worked in the easiest areas related to the processing of fabrics, tailoring.

The only survey related to the Jewish woman-artisans involved 161 women who lived in four cities: Vilno (Lithuania), Warsaw (Poland), Berdichev (Ukraine) and Brezin (Russia). According to it, the average employment rate of Jewish women in tailoring was $27,5 \%(15 \%$ in Warsaw, $18 \%$ in Brezin, up to $38 \%$ in Vilno and $39 \%$ in Berdichev). Women participated in crafts only at a young age, most of them left this work after marriage. Occasionally, there were family workers, but they were either widows or women who were left by their husbands. Therefore, Jewish women participated in craft exclusively through some exceptional circumstances, urgent need. The highest age group of Jewish women engaged in the tailoring was $28-30$ years old. The median number of years that employees have worked was 5 years $[7,131]$.

Table 1. Age structure of Jewish women tailors

\begin{tabular}{|c|c|c|c|c|c|c|c|c|c|c|}
\hline \multicolumn{10}{|c|}{ Years of experience } \\
\hline experience & 1 & 3 & 4 & 5 & 6 & 7 & 8 & 9 & 10 & $\begin{array}{c}\text { More } \\
\text { than } 10\end{array}$ \\
\hline 3 & 10 & 21 & 24 & 27 & 14 & 8 & 5 & 3 & 8 & \\
\hline \multicolumn{10}{|c|}{ Number of workers } \\
\hline
\end{tabular}


In tailoring, woman did not require complex professional training. They often skipped the apprenticeship stage and started working as artisans. Women received one half of men' wage. Women salaries had been rising steadily for 10 years, from 1,86 to 5,86 roubles per week. However, after 10 years of work, they falled to 3,90 roubles per week. They were predominantly illiterate women; the literacy rate was $27,4 \%(1,6 \%$ for illiterate men) $[7,132]$.

These data, although incomplete, allow us to present general trends in the participation of Jewish women in crafts in the Russian Empire, since textile-related handicrafts were the most popular. It can be assumed that working conditions were rather difficult due to low mechanization of labor and growing competition, a decrease in profits as a result of the emergence of wholesalers who became intermediaries between artisans and consumers of their products.

After the October Revolution of 1917 and forming the Soviet Union in 1922, the situation changed dramatically. Those Jews who remained in the Soviet Union and did not emigrate had to adapt to their new life. During 1920s, USSR pursued multi-vector and contradictory economic policy.

The policy of War communism of 1919-1920, is characterized by the expropriation of private business and the nationalization of industry. This led to the destruction of the foundations of the Jews economic life, its total impoverishment. Because of the pogroms, many Jewish artisans were killed or robbed. New Economic Policy, implemented by the Soviet Government in 19211928 , represented a temporary retreat from its previous policy of extreme centralization and doctrinaire socialism. These measures included the return of retail trade, rent and private ownership, wage labour etc. Since 1928, the Soviet authorities began a state-run program of rapid industrialization and all elements of capitalism provided by NEP were abolished.

We must take into account that since the second half of the 1920s, the Soviet Union started the involvement of Jews in the productive labor manifested in the "reconstruction" of the Jewish economy and society. This implied a significant increase in Jewish employment in industry and agriculture. According to the five-year plan for "Jewish reconstruction", which began in parallel with the first five-year plan in 1928, it was planned to reduce the number of Jewish artisans by one third. At the same time, the number of Jewish workers was expected to increase by $91,9 \%$, Jewish peasants by $20 \%$ [8]. With regard to women, the Soviet Union declared the emancipation.

The revival of handicrafts industry started in 1920 with several decrees of the Soviet authorities, but the most favorable conditions were created by NEP. Since May 1921, small producers received the right to free exchange, purchase and sale of handicraft products. This led to a significant increase in the number of artisans, including among the Jews.

In 1926, there were 1574100 Jews living in Ukraine [8]. Artisans made up approximately $10 \%$ of this population and $19 \%$ of all self-employed Jews (persons who received income from various sources) - 154493 persons. Despite the number of Jewish artisans increased slightly by $25 \%$, there has been a significant increase in the number of single artisans $(51,7 \%)$ and decrease of artisans employed a hired labor $(6,1 \%)$ [9, 55-56].

Table 2. Professional structure of Jews artisans (Census 1926) [9, 60-61]

\begin{tabular}{|l|c|c|c|}
\hline Groups of professions & $\begin{array}{c}\text { Absolute } \\
\text { number }\end{array}$ & $\begin{array}{c}\text { \% to the total number of } \\
\text { Jewish handicraftsmen }\end{array}$ & $\begin{array}{c}\text { \% of Jews to all } \\
\text { handicraftsmen Ukrainian SSR }\end{array}$ \\
\hline Metalworkers & 13513 & 10,7 & 35,9 \\
\hline Sewing workers & 42487 & 33,6 & 52,6 \\
\hline Leatherworkers & 23713 & 18,8 & 24,8 \\
\hline Woodworkers & 8583 & 6,8 & 23,4 \\
\hline $\begin{array}{l}\text { Textile workers and } \\
\text { knitwear workers }\end{array}$ & 6396 & 5,1 & 36,8 \\
\hline $\begin{array}{l}\text { Printers and stationery } \\
\text { workers }\end{array}$ & 2975 & 2,3 & 86,3 \\
\hline Food workers & 14581 & 11,5 & 49 \\
\hline Builders & 4942 & 3,9 & 13,6 \\
\hline Others & 9300 & 7,3 & 37.6 \\
\hline Totally & 126500 & 100 & 34,8 \\
\hline
\end{tabular}


The highest concentration of Jewish women in the artisan industry is found in the industries that employed the largest number of Jews. These crafts are following: garment $40 \%$, textile knitting 38,2\%, food $24,7 \%$ and printing $12,4 \%$. Woman represented about 19,5\% of Jewish artisans [9, p.60-61]. This is an official statistics, but a certain number of artisans of both sexes have been operating in the shadows, however it is impossible to reconstruct their reliable number in order to avoid taxation, many artisans concealed their activities. Women were the most disadvantaged, concentrating in areas that worked on scarce raw materials (fabrics). While middleaged Jews predominated among men, women were younger. This can be explained by the high employment of women in family business.

Table 3. The age structure of Jewish women artisans (Census 1926 [9, 61-62])

\begin{tabular}{|c|c|c|}
\hline Age & \% ratio of age groups of woman & \% ratio of age groups of man \\
\hline $0-15$ & 2 & 2 \\
\hline $16-17$ & 5,7 & 3,8 \\
\hline $18-19$ & 8,5 & 4,2 \\
\hline $20-24$ & 20,5 & 11,6 \\
\hline $25-34$ & 27,2 & 26,2 \\
\hline $35-44$ & 17,9 & 20,5 \\
\hline $45-54$ & 10,9 & 15 \\
\hline $55+$ & 7,3 & 16,7 \\
\hline total & 100 & 100 \\
\hline
\end{tabular}

The Soviet authorities' attitude to all artisans was ambivalent. On the one hand, they were poor labourers and produced their own products, on the other hand, they were owners of tools, means of production and the goods produced. Accordingly, all artisans were divided into three groups, depending on the use of hired labour and four groups depending the turnover of money. Although these groups were treated differently, many artisans, including Jews of both genders, suffered from the following: high taxes; arbitrariness of the authorities, especially when calculating the tax; inability to obtain credit from the State; lack of raw materials; high competition among Jewish artisans; low mechanization and productivity of work; inability to compete with the large-scale industrial enterprises. By the end of NEP, many artisans were disenfranchised which significantly worsened their economic position.

As many artisans were considered by local authorities as "non-working"elements (they worked to provide for themselves and not on the state's fovour), they were often illegally over-taxed.

We found in archival materials complaints about the willfulness of the authorities of several Jewish women artisans. They were adressed to the Central Committee of the Workers' and Peasants' Inspection and Central Committee of National Minorities under the All-Ukrainian Central Executive Committee.

One of them was Lagronskaya Ida Piisukhovna from Uman. She had been an artisan since 1927, and as a single artisan, herself made and sold felt hats for Ladies. She was illegally subjected to an additional (industrial and income tax) and all her raw materials - caps for hats were taken as pledge. In addition, authorities removed all furniture and property from her house. At the same time, she still had to pay the tax authorities several hundred rubles of debt. It was done illegally, because only ready goods could be picked up. More, she belonged to the group of a single artisants which due to the law of 1925 were exempted from paying tax. Another artisan Golda Weiner living in the village of Lianscorun was expelled from the artel and evicted. Obviously this situation lasted for a long time as Central Committee of National Minorities asked the village council why she was not given a dwelling and other person was hired to artel istead of she $[10,128]$.

Describing the working conditions of women artisans, one should underline the fierce competition among artisans. Knitting was the most popular craft among the Jews. According to 
ORT data, by 1928 about 4,000 artisans were working in this handicraft, of whom $80 \%$ were Jews, of whom $70 \%$ were women $[11,5]$.

Why did knitting was the most popular craft among Jews? In the USSR and in the Ukrainian SSR, the shortage of consumption goods led to the priority demand for clothing, so artisans involved in their production always had job and a wide market for selling. Demand for this equipment was 5 times higher than real demand on the market. Documents of Kyiv ORT Committee for 1928 mentioned boom that developed around the purchase of sewing and knitting equipment. The artisans who had such equipment were called «lucky», persons who could earn 20-30 rubles per day. Equipment was seen an important factor of the increasing the productivity and tool for the survival of artisanal families. However, the equipment was expensive and could cost up to 1,000 rubles $[12,3]$. ORT provided significant assistance to Jewish artisans. Thus, artisans of Kyiv received 2,161 pieces of equipment (89,1\% of all appeals), of which 721 arrived in Kyiv, and 1,440 in Kyiv region in 1928 [13, 21].

Life of women-artisans in the USSR was quite heavy. They suffered from 1) shortage of raw materials and equipment; 2) irregular working hours; 3) low wage (especially in embroidery); 4) need to combine work with family responsibilities and child-rearing, which was especially hard, considering the small number of nurseries and kindergartens. This was even mentioned in the Soviet press and during the first All-Union and all-Ukrainian meetings of woman-artisans hold in $1928[14,2]$.

From the second half of the 1920s, the Soviet authorities began to force artisans to unite in an artels (cooperative associations) - joint enterprisers completely controlled by the government. According to plans of the Soviet authorities, they were to transform from idependant producers into dependent employees who had to fulfill directives of the Soviet economy. The handicraft industry was regarded by the Soviet authorities as a base and reserve for the development of a large-scale industrial enterprises. This situation worsened in 1928, when the Soviet Union began industrialization and its first five-year plan. Single artisans had to choose between being left out of economic life, cooperating (joining into artels) or changing profiles -mainly join the ranks of the proletariat.

What have Jewish artisan women done in this situation? We have no reliable answer. We can only speculate. From 1926 to 1939, employment among Jews over 15 years old increased from $46 \%$ to $58 \%$, including women from $23 \%$ to $41 \%$ [15]. Thus, the employment of Jewish women increased. It can be assumed that some of the Jewish women have joined in the arteries, and some have found work as employees or workers.

The Soviet authorities essentially increased the involvement of women artisans in arlels only in the early 1928, after the All-Union Congress of Women Artisans, held in Moscow in February, and the All-Union Conference and All-Ukrainian Congress of Women Artisans in Kharkiv held in March.

By this time a total of 13,422 women artisans were cooperated in joint enterprises, of whom $98,5 \%$ were employed in the textile industry $[14,2]$. In parallel with the cooperation of women in the artel, the Soviet government made an attempt to involve women in industrial production and participation in the councils of all levels - bodies elected by population.

Women who began to unite in artels also faced many difficulties. Despite the fact that the Soviet government pledged to support the artels with loans and raw materials (unlike single artisans), this obligation was often not fulfilled. Therefore, woman artisans suffered from lack of raw materials as well as of funds in cooperatives, inability of improving production; low level of qualification; illiteracy, which prevented improving qualification; poor equipment; poor management of arteries. Most of them were overcome only in the early 1930s.

Conclusions. Therefore the following conclusions of our research can be drawn. Both in the Russian Empire and in the USSR, the particiating in handicrafts was a means of economic survival for women. However, in the USSR, women's participation in economic life began to take on a political connotation, which manifested itself in the emancipation and desire to participate 
actively in social and political life. Despite the seemingly favourable conditions for engaging in handicrafts in the USSR during the NEP period, this activity was complicated by various methods of pressure of the Soviet authorities. We can state that woman artisans waged a daily struggle for survival: for credit, for raw materials, against the willfulness of the authorities. Many of them, unable to withstand the pressure of power and taking into account the Soviet policy of industrialization and «reconstruction of the Jewish economy», began to unite in joint enterprises or join the ranks of the Soviet proletariat. In result, they lost independance and transformed in the hired workers fulfilled the tasks of the Soviet authorities. Handicraft was left by many former artisans as an informal supplementary activities for earning money. With regard to the answer to the main question of the research «struggle or adaptation» of Jewish woman-artisans, we should state that fight for the survival in the 1920s and early 1930s, took the form of adaptationis to the situation in the USSR (UUkrainian SSR) in different time periods.

\section{Список використаної літератури}

1. Козерод О.В. Гендерні аспекти історії українського єврейства (на прикладі періоду 20 -х років ХХ ст.) / О. В. Козерод. - Київ : Радуга, 2013. - 101 с.

2. Artisan [Електронний ресурс]. - Режим доступу: https:/dictionary.cambridge.org/dictionary/ english/artisan.

3. Craft [Електронний ресурс]. - Режим доступу: https://dictionary.cambridge.org/dictionary/english.

4. Первая всеобщая перепись населения Российской империи 1897 г. Том XVI. Киевская губерния / Под ред. Н.А. Тройницкого. - Санкт-Петербург: Типография В.А. Мещерского. -287 с.

5. Бланк Р.М. Роль евреев в экономической жизни России / Р.М. Бланк. - Санкт-Петербург: Типография Первой Спб. трудовой артели, 1908. - 64 с.

6. Марголин С.О. Евреи-труженники / С. О. Марголин. - Санкт-Петербург: Капитал, 1910. - 48 с.

7. Материалы и исследования еврейской портняжной промышленности. Том 2. Портняжный промысел / Под ред. С. О. Марголина. - Санкт-Петербург: Правда, 1915. - 152 с.

8. Всесоюзний перепис людності 1926 року. - Том XI: Українська Соціялістична Радянська Республіка. Підсумки по Республіці. Полісся: Національність, Рідна Мова, Вік, Письменність / Центральне статистичне управління СРСР, Відділ перепису. Москва: Видання ЦСУ Союзу РСР, 1929. - $210 \mathrm{c}$.

9. Зингер Л. Еврейское население в Советском Союзе / Л. Зингер. - Москва; Ленинград: Соцегиз, 1932. $-160 \mathrm{c}$.

10. Жалоба // ЦДАВО, Фонд 413, оп.1, спр. 479, арк.128.

11. Протокол №2 Заседания Подкомиссии по новым промыслам и реконструкции существующих от 28.06.1928 г. // ДАКО, Ф.3669, оп.1, спр. 14, арк.5.

12. Новые чулочные, китлевочне машины и гидравлический пресс. // Кооперированный кустарь. - 1928. - 1 апреля. - С.3.

13. Снабжение еврейских кустарей машинами // Трибуна еврейской общественности. - 1929. №6. - C.21.

14. За механізацію виробництва, за підвищення кваліфікації, за кращу якість виробництва. Перша всеукраїнська нарада та Всесоюзний з'їзд кустарок. // Кооперативный кустарь. - 1928. 8 марта. - C.2.

15. Всесоюзная перепись населения 1939 г. Основные итоги. Под ред. Ю.А. Полякова. - Москва: Наука, 1992. - 256 с.

\section{References}

1. Kozerod O.V. (2013). Gender aspects of the history of Ukrainian Jewry (on the example of period of the 20 s of the XX century). Kiev: Raduga. (in Ukr.)

2. Artisan. Retrieved from: https://dictionary.cambridge.org/dictionary/english/artisan. (in Engl.)

3. Craft. Retrieved from: https://dictionary.cambridge.org/dictionary/english/craft.(in Engl.)

4. The first general census of the population of the Russian Empire in 1897. (1897). Volume XVI. Kiev province / Ed. O.N. Troinitsky. St. Petersburg: V.A. Meshchersky printing House. (in Rus.)

5. Blank R.M. (1908). The role of Jews in the economic life of Russia. St. Petersburg: Printing House of the First St. Petersburg labor artel. (in Rus.) 
6. Margolin S.O. (1910). Jewish workers. St. Petersburg: Capital. (in Rus.)

7. Materials and research of the Jewish tailoring industry. Volume 2. Tailoring (1915). Eds. S. O. Margolin. St. Petersburg: Pravda. (in Rus.)

8. All-Union population census of 1926. Volume XI: Ukrainian Socialist Soviet Republic. Results on the Republic. Polisya: nationality, native language, age, literacy (1929). Moscow: Vidannya TsSU Soyuzu RSR. (in Ukr.)

9. Singer L. (1932). The Jewish population in the Soviet Union. Moscow-Leningrad: Sotsegiz. (in Rus.)

10. Complaint / TSDAVU, F.413, op.1, sprava 479, ark.128. (in Rus.)

11. Protocol No. 2 of the Meeting of the Sub-Commission on new trades and the reconstruction of existing ones dated 06. 28. 1928. DAKO, F.3669, op.1, sprava 14, ark.5. (in Rus.)

12. New hosiery, witching machines and hydraulic press (1928). Cooperative handicraftsman, April 1 , 2. (in Ukr.)

13. Supply of Jewish handicraftsmen with equipment (1929). Tribune of the Jewish community, 6. 21. (in Rus.)

14. For the mechanization of the production, for the advancement of the quality, for the improvement of the quality of the production. The first All-Ukrainian Meeting and All-Union meeting of Handicrafts (1928). Cooperative Handicraft, March 8, 2. (in Ukr.)

15. All-Union Population Census 1939. Main results. Eds. Yu.A. Polyakova. Moscow: Nauka. (in Rus.)

ПЕРГА Тетяна Юріївна, кандидат історичних наук, старший науковий співробітник ДУ «Інститут всесвітньої історії НАН України»,

e-mail: pergatatiana@gmail.com

\section{ЄВРЕЙСЬКІ ЖІНКИ-РЕМІСНИЦІ В УКРАЇНСЬКІЙ СРР У 1920-х рр.: БОРОТЬБА АБО АДАПТАЦІЯ?}

Вступ. У статті досліджується наукова проблема участі єврейських жінок в індустріальній праці, зокрема в кустарно-ремісничій діяльності. Дослідження здійснено на прикладі Украйнської CPP періоду 1920-х рр.

Новизна. Актуальність розвідки зумовлена нерозкритістю иієї теми в наукових праиях вітчизняних та закордонних фахівиів.

Мета. Розкрити особливості участі єврейських жінок у ремісничій діяльності у 1920-х роках.

Методи. Джерельною базою статті є статистичні дані перепису населення у Російській імперії та в СРСР, спеціалізовані огляди економічної активності євреїв до і після 1917 р., а також архівні матеріали. Дослідження проведено на основі порівняльного аналізу залучення єврейських жінок до участі у ремісничому виробництві в Російській імперії та в СРСР.

Результати. Зроблено висновок, щзо головними причинами участі єврейських жінок у ремісничій діяльності в обох імперіях були економічні. Розкрито специифіку зайнятості єврейських жінок в кустарно-ремісничому виробництві, їхній віковий і професійний склад. Автор резюмує, щзо у 1920-х рр., в умовах багатовекторної економічної політики радянської влади (воєнного комунізму, НЕПу, індустріалізації) єврейські жінки-кустарі змушені були вести щоденну боротьбу за виживання і протистояти багатьом проблемам, наприклад свавіллю влади, особливо під час обкладання податками; нестачі сировини і відсутності доступу до державних кредитів; а також високої конкуренції у своєму середовищі та з фабрично-заводською промисловістю, поєднання роботи з вихованням дітей, низького рівня освіти та механізації прачі тощо. Значну допомогу кустарям надавав ОРТ, однак він не міг забезпечити усі потреби кустарів у техніиі.

Висновки. Курс радянської влади на кооперування поставив перед жінками кустарями дилему: об'єднуватися в артілі або поповнювати ряди робітників різних підприємств, переважно індустріальних. У ичих умовах ремісничий промисел, особливо пов'язаний з обробкою тканин, був залишений переважно як додатковий підпільний заробіток.

Ключові слова: євреї, жінки, кустарі, економіка, НЕП, СРСР, УСРР, Російська імперія. 